Pregledni znanstveni članek Review scientific paper (1.02) Besedilo prejeto Received: 18. 1. 2021; Sprejeto Accepted: 12. 2. 2021

UDK UDC: $26-45$

DOI: $10.34291 /$ Edinost/76/Saje

(C) 2021 Saje CC BY 4.0

\title{
Andrej Saje
}

\section{Sklepanje zakonske zveze v tradicionalnem judovstvu}

\author{
Contraction of Marriage in Traditional Judaism
}

Izvleček: Narodi in ljudstva so skozi zgodovino oblikovali norme, ki urejajo medsebojne odnose. Judovsko pravo je v tem smislu posebno, ker ni sistem uredb posamezne države, temveč ljudstva z več kot 3000-letno zgodovino. Redko so živeli v suvereni državi, največkrat so bili razpršeni po svetu in so živeli v različnih družbenih ureditvah. Raznovrstni pravni sistemi so deloma vplivali tudi na razvoj judovskih pravnih norm, vendar pa so hkrati ohranili avtonomijo, kar je posebej vidno pri obredu poroke. Zakonska zveza je zanje religiozni institut, podvržen Božjim zakonom. Judovsko zakonsko pravo ima posledično nalogo etične in religiozne ideale zakonske zveze, predpisane s Postavo, umestiti v konkretno življenje in prakso. V tem smislu zakonsko pravo poročne slovesnosti izvzema iz zgolj zasebne sfere zaročencev in njihovih družin ter poudarja družbeni in nravstveni značaj tega instituta ter z njim uresničitev Božjega načrta s človekom, »ki mu ni dobro samemu biti« (1 Mz 2,18). Preroki primerjajo zakonsko zvezo z zavezo med Bogom in izraelskim ljudstvom. Njihov zakon ni zakrament $\mathrm{v}$ krščanskem smislu, temveč je mitzwa, tj. izpolnitev verske zapovedi. Je sveta zaveza berith, ki s seboj poleg pravic prinaša tudi dolžnosti. Zakonska zveza je namenjena človeškemu razmnoževanju, osrečevanju človeka v skupnosti z drugim, ima pa tudi velik družbeni pomen. V članku so predstavljene judovske poročne posebnosti, ki izhajajo iz hebrejske Biblije in rabinske tradicije, kjer se zakon sklepa po stopnjah. Dotaknemo se tudi vprašanja ločitve zakoncev.

Ključne besede: judovska poroka, zakonska zveza v Svetem pismu, zaroka, poročni običaji, ločitev, zaveza

\begin{abstract}
Nations and peoples throughout history have formulated norms that govern interpersonal relations. In this sense the Jewish Law is unique, as it is not a system of regulations of a state but of a people with more than 3000 years of history. They have rarely lived in a sovereign state of their own; they have most often been dispersed throughout the world and lived in different social orders. Various legal systems have had some influence on the development of Jewish legal norms; nevertheless, the Jews have preserved their autonomy, which is particularly evident in their wedding rites. They consider marriage a religious institution that is subject to divine laws; consequently, the Jewish marriage law has to implement the ethical and religious ideals of marriage as ordained by the Law in concrete life and practice. In this sense the Jewish marriage law extracts the celebration of marriage from the private sphere of the fiancés and their families and emphasizes the social and moral character of this institution and its fulfillment of the divine plan for human beings, for it is "not good for the man to be alone" (Gen 2,18). The prophets compare the marriage bond to the covenant between
\end{abstract}


God and the chosen people of Israel. The Jewish marriage is not a sacrament in the Christian sense but a mitzvah, that is, a fulfillment of a religious commandment. It is a berith, a holy covenant that entails rights as well as duties. The marriage bond is intended for humans to proliferate and to make them happy in communion with another; it is thus of great social importance. The article presents particulars of the Jewish wedding and marriage practice, which come from the Hebrew Bible and rabbinic tradition, whereby marriage is contracted in stages; it also deals with the question of divorce.

Key words: Jewish marriage, marriage bond in the Bible, engagement, wedding customs, divorce, covenant

\section{Umestitev tematike ${ }^{1}$}

Krščansko pojmovanje zakonske skupnosti kot zveze med možem in ženo, ki jo je Kristus Gospod povzdignil v dostojanstvo zakramenta (ZCP, kan. 1055 \1), ima bogato predzgodovino v starih kulturah, predvsem v semitski, grški, rimski in germanski tradiciji. (Saje 2003,9-20) Sklepanje zakona je skozi zgodovino spremljalo določeno zunanje obredje, ki je bilo odvisno od prevladujoče tradicije, kulturnega ozadja in še posebej od religije. (Commissione teologica internazionale 1977, 1.1) Poročni obred se je sčasoma spreminjal in dopolnjeval. Za vse stare tradicije in religije je značilno, da ima poroka $v$ družbi posebno mesto in pogosto tudi sakralen značaj, kar je značilno tudi za judovstvo. (Ritzer 1962, 1-2; Colorni 1945, 182) To ljudstvo veruje, da Bog vodi zgodovino, čeprav v konkretno dogajanje ne posega in ga vodi na skrivnosten način. (Avsenik Nabergoj 2020, 23) S sklenitvijo zakona se formalno ustanovi družina kot pomemben družbeni institut in na ta način zagotovi nadaljevanje človeške vrste. Zakonska zveza presega zgolj zasebni interes moža in žene in je stvar širše skupnosti. Posledično so družbene in verske strukture sklepanje zakona ščitile in regulirale. Določale so pogoje za poroko in načine, kako se sklenitev zakona formalizira tudi navzven. (Gaudemet 1989, 36; Saje 2018, 814) V tej razpravi se osredotočamo na judovske poročne posebnosti, ki izhajajo iz hebrejske Biblije in rabinske tradicije.

Prebivalci starih kultur so partnersko zvezo med možem in ženo dojemali kot nekaj naravnega. "Stvarnost so dojemali kot racionalno urejeno, človeka pa kot razumno bitje, ki je sposobno uskladiti svoje delovanje

1 Članek je nastal kot rezultat dejavnosti raziskovalnega programa P6-0262 Judovsko-krščanski viri in razsežnosti pravičnosti, ki ga je sofinancirala Javna agencija za raziskovalno dejavnost Republike Slovenije iz državnega proračuna.

Edinost in dialog 76 (2021) 1: 203-217 
z univerzalnim redom, trdnim in trajnim, nasproti njegovi minljivosti in negotovosti." (Globokar 2019, 613) Judovsko razumevanje sveta, ki ga je kasneje prevzelo tudi krščanstvo, človeka ne razume kot produkt naključja evolucije, temveč je vsaka oseba izraz Božje podobe in udejanjenje Božje modrosti. (Palmisano 2020, 43) Bog je človeka ustvaril po svoji podobi kot moškega in žensko (1 Mz 1,27). Judovstvo, kakor ga predstavlja Sveto pismo in ga razlagata Talmud ter rabinska tradicija, sprejema institut zakonske zveze skupaj z drugimi predpisi v sklopu hebrejske tradicije, kjer je za razliko od preostalih religij poudarjen monoteizem. (Segre 1980, 19) Za jude, ki verujejo, da je Bog ustvaril svet in povezal nebo in zemljo v eno enoto, je v središču človek, ki mora svoje življenje uravnavati v skladu z duhom monoteizma in Božjih načrtov s človekom. Vera v enega Boga, poudarja judovski rabin Lattes, mora prežemati celotno življenje posameznika v njegovem individualnem ali kolektivnem načinu izražanja vere. (1976, 8-10) Vstopiti mora ne zgolj v človekovega duha, temveč v njegovo življenje in mu dati smer za konkretno ravnanje.

\section{Posebnosti judovskega prava}

Z razumevanjem judovskega sklepanja zakonske zveze in poročnih slovesnosti se moramo najprej dotakniti njihovega razumevanja prava in prepletenosti teh norm z moralnimi predpisi, simbolne govorice (Krašovec 2016, 572 ) in razlik teh postulatov v odnosu do latinske tradicije. Zahodna pravna kultura je pravo razdelila na naravno in pozitivno pravo. Prvo človeka navdihuje $\mathrm{k}$ določenim oblikam vedênja, ne na podlagi zunanjih predpisov, temveč na osnovi tega, kar človek z razumom spoznava v sebi iz narave same. Pozitivno pravo je sad človekovih odločitev in spoznanj skozi zgodovino, ki se konkretizirajo v obliki zunanjih predpisov in norm. Medtem ko pravo dejanja presoja na podlagi zunanje norme z vidika učinka, morala gleda na izvor nekega dejanja, ki se presoja v vesti. (Saje 2009, 1114) Za razliko od zahodnega razumevanja prava in morale so $v$ judovstvu, tako bibličnem kot postbibličnem, moralne in pravne norme med seboj močno prepletene. V Pentatevhu ni mogoče postaviti stroge meje med moralnimi nauki in zakonskimi predpisi. Moralnost mora biti uzakonjena z napisano normo, pravo se ne izvaja zgolj na postulatih kreposti pravičnosti, temveč je v končni fazi izraz ljubezni. (Lattes 1976, 300) 
Judovsko pravo ni sistem zakonov neke države, temveč gre za predpise izvoljenega Božjega ljudstva. Judje so v večtisočletni zgodovini redko živeli v svoji državi, kljubovali so različnim vladavinam in raznim zunanjim juridičnim sistemom ter tujim kulturnim vplivom. Njihov pravni sistem ne zadeva zgolj zemeljskega reda, temveč temelji na zavezi z Bogom Jahvejem in se ozira nanjo. Izhaja iz Božjega razodetja izraelskemu ljudstvu, kakor je zapisano v petih Mojzesovih knjigah in drugih pravnih virih, kot so Mišna, oba Talmuda in preostali predpisi. (Homolka 2009, 1-7) Biblična izraza za pravo sta mischpat in din, pri čemer je njun jasni pomen v besedilih težko razlikovati. Mischpat opredeljuje sistem državljanskih zakonov in predpisov, ki vključujejo kazensko in versko pravo. Ureja odnose med ljudmi in odnose ljudi z Bogom. (Menachem 1994, 105) Beseda din se v smislu 5 Mz 17,8 uporablja v kontekstu pravnih predpisov, ki se tičejo sporov oz. medčloveških odnosov nasploh. Omenjeni izraz se v Talmudu kasneje uporablja tudi za poimenovanje premoženjskega prava (dine mamonot), za družinsko pravo in vprašanja zakonske zveze (dine mischpacha), za kazensko pravo (dine nefaschot) ter državno pravo (dine ha-malchut). Judovsko pravo se v času med padcem drugega templja leta 70 po Kr. in začetkom 3. stoletja dopolni in ga poimenujejo halacha. Slednje vsebuje tudi predpise glede poročnih slovesnosti in družinskega prava. (Homolka 2009, 1-2)

\section{Pojmovanje zakonske zveze}

Mojzesovo Peteroknjižje poroko zgolj omenja, vendar pa v njej ne najdemo natančnejših opisov tega obreda. Iz bibličnih poročil tudi ni mogoče zaključiti, da bi v judovstvu obstajal enoten in obvezen poročni obred. (Colorni 1945, 182) Na podlagi pripovedi o poroki Izaka in Rebeke (1 Mz 24,67) lahko sklepamo, da so se judje poročali v domačem okolju v skladu z družinsko tradicijo. Za jude zakon presega zgolj interes zaročencev ali njunih družin in je religiozni institut, ki je podvržen Božjim zakonom. (DellaPergola 2003, 2) Zakonska zveza je izvzeta iz zgolj zasebnega ali pogodbenega prava zainteresiranih oseb in postane etični model zaveze med Bogom in Božjim ljudstvom (Oz 1-3). Kot znamenje zaveze (1 Mz 17,11-12) in odgovornosti do zakonskega življenja v skladu s Postavo so bili moški obrezani. (Segre 1980, 27) 
Judje so zakonsko zvezo visoko cenili in si jo želeli, samskost je bila razen redkih izjem nezaželena, ker se ne sklada z Božjimi načrti za človeka. Judovski zakon ni zakrament v krščanskem smislu (Segre 1980, 24), ima pa na podoben način značaj sakralnosti in posvečenosti. Razumejo ga kot mitzwa, tj. izpolnitev Božjega zakona. Hkrati je berit, tj. sveta zaveza, ki s seboj prinese tudi določene dolžnosti. (Homolka 2009, 33) Zakonca sta drug drugemu in Bogu zavezana v zvestobi in medsebojni ljubezni, njuna hiša pa je poimenovana sveti prostor (Ps 29,2).

Glede judovske zakonske zveze so na podlagi Postave razvidni trije nameni. Zakon je najprej določen za nadaljevanje človeške vrste (1 Mz 1,28) in bivanje ljudi na zemlji v teku zgodovine (Iz 45,18). Drugi namen je blagor zakoncev in njuna medsebojna sreča, ker ni dobro, da je človek sam (1 Mz 2,18). Kot tretji cilj je podčrtano družinsko življenje, ker sta pri judih zakon in družina temelj družbe in njenega napredka. Zaradi tega bo mož zapustil svoje starše in se pridružil ženi in bosta eno telo (1 Mz 2,24).

Poligamija je bila v skladu s Postavo in v Talmudu dovoljena za moške, podobno kot $\mathrm{v}$ kulturah, $\mathrm{s}$ katerimi so bili judje $\mathrm{v}$ stiku, ni pa bila dovoljena poliandrija. (DaDon 2018, 133) Vse žene enega moža so imele enak pravni status, enako kot bi bile v monogamni zvezi. Za vsako od teh žena je zakonska zveza prenehala samo z ločitvijo ali s smrtjo moža. Očak Jakob se je poročil z dvema ženskama, Leo in Rahelo (1 Mz 29,15-30), prav tako Abraham. (DellaPergola 2003, 2) Dve ženi naj bi imel tudi Mojzes, Kušijko in Ciporo, vendar si glede tega razlagalci niso enotni in ju včasih jemljejo kot isto osebo. (Homolka 2009, 35) Nekatere druge znane svetopisemske osebe, ki so imele več žena, so še Gideon (Sod 8,30), Elkana (1 Sam 1,2), Salomon (1 Kr 11,3) in Jojada (2 Krn 24,3). V nasprotju s to prakso imamo v Svetem pismu znane primere monogamije, začenši s poročilom o stvarjenju (1 Mz 1-2), ali pa primer vrle žene (Prg 31,10-31). Veliki duhovniki so morali biti poročeni, vendar samo z eno ženo (3 Mz 21,13). Slednja je morala biti devica, vdove in ženske na slabem glasu so bile izključene. Kar se tiče dejanske poročne prakse, je kljub prvotno dovoljeni poligamiji skozi zgodovino vse bolj prevladovala monogamija, še zlasti v kasnejšem obdobju, ko se je judovstvo srečalo z grško, rimsko in kasneje s krščansko kulturo in versko tradicijo. (Homolka 2009, 36) 


\section{Predpostavke za sklenitev zakona}

V skladu z judovskim pravnim redom se je lahko poročila oseba, ki je bila zmožna sklepati pravne posle. Gluhonemi, neprištevni in mladoletni praviloma niso imeli sposobnosti sklepanja zasebnopravnih pogodb. (Homolka 2009, 40) Po razlagi Talmuda je morala žena v zakon privoliti, vendar pa se je njeno molčanje pri izmenjavi privolitve obravnavalo kot strinjanje (bT Qid 2b). V tradicionalnem judovskem pravu obstaja predpisana različna minimalna starost za fante in za dekleta. Deček je bil do trinajstega leta mladoleten (katan) in do te starosti veljavnega zakona ni mogel skleniti. Z izpolnjeno predpisano starostjo je pridobil pravice in dolžnosti odraslega moškega in se je teoretično lahko poročil, vendar pa Mišna priporoča nekoliko višjo starost - osemnajst let. Talmud kot primerno starost za ženitev omenja obdobje med šestnajstimi in dvaindvajsetimi leti (bT Qid 30a). Za deklice je veljalo, da so mladoletne do dvanajstega leta starosti (ketana). Ko dekle doseže to starostno obdobje, postane odrasla (gedola). Kot mladoletna se deklica ni smela poročiti, v redkih izjemah je bila poroka dopustna s privolitvijo očeta. Talmud poroke mladoletnic ni dovoljeval (bT Qid 41a), kasneje jih je tudi izrecno prepovedal. (Goldfine 1975, 31)

Poroka med bližnjimi sorodniki je bila po judovskem pravu prepovedana (3 Mz 18,6-20; 20,10-21; 5 Mz 27,20-23). Pravo je načeloma prepovedovalo zakonsko zvezo med vdovo in bratom njenega pokojnega moža in ga označevalo kot incest, vendar v Peteroknjižju najdemo primere, kjer je bilo to dopustno, če vdova ni imela otrok oz. zaradi nadaljevanja potomstva. "Če bratje bivajo skupaj in eden izmed njih umre, pa nima sina, naj se žena umrlega ne moži s tujcem. Njen svak naj gre k njej in si jo vzame za ženo in ji izpolni svaško dolžnost. Prvorojenec, ki ga bo rodila, naj se imenuje po njegovem umrlem bratu, da se njegovo ime ne izbriše iz Izraela.«(5 Mz 25,5-6)

Prepovedana je bila poroka s tujci ( 5 Mz 23,3; Ezr 9,12), devištvo je bilo pogoj za veljaven zakon, v nasprotnem primeru so lahko nevesto kaznovali s smrtjo, ženinu, ki bi jo po krivem obtožil izgube nedolžnosti, preden sta prišla skupaj, pa se je naložila zgolj denarna kazen. Udejanjenje nedovoljenega poželenja je bilo strogo sankcionirano (Skralovnik in Matjaž 2020, 507). Prešuštvo tako moških kot žensk se je kaznovalo s smrtjo. Storilec spolnega nasilja nad zaročeno žensko je bil kaznovan s smrtjo, medtem 
ko žrtve v tem primeru kazen ni zadela. Če je moški spal z devico, je moral njenemu očetu plačati odškodnino in jo vzeti za ženo in je ni smel odsloviti (5 Mz 22,13-29). Glede vprašanja, ki se je postavilo po babilonskem eksilu, ali je dovoljen zakon med judom in nekom, ki je sprejel judovsko vero, Ezra odločno odgovarja nikalno (Ezr 10,10). Avtor Rutine knjige v nasprotju s tem, morda iz kljubovanja, poudarja Homolka (2009, 51), pa takšno poroko dovoljuje (Rut 1,1-22).

\section{Poroka po stopnjah}

Svetopisemska poročila na več mestih govorijo o poroki, za sklenitev zakona dajejo navodila ali pa določajo prepovedi, samega poročnega obreda pa natančneje ne opisujejo. Kljub pomanjkanju zgodovinskih virov za to obdobje avtorji judovske običaje poročanja razvrščajo na tri glavne stopnje. (Meacham 2020, 1) Zaročenca sta se morala na začetku s svojimi družinami dogovoriti glede dote (Mòhar), ki jo je zaročenec moral plačati družini neveste. Primer ureditve vprašanja dote najdemo v 1 Mz 29, kjer je moral Jakob, da bi se lahko poročil z Rahelo, v Labanovi družini delati sedem let. Po ureditvi tega vprašanja je par začel bivati pod isto streho. Z začetkom skupnega bivanja je bila postavljena domneva, da sta zaročenca zakon s spolnim dejanjem izvršila (Biàh). Tretja stopnja poročnega ceremoniala je vsebovala pisni dogovor (Shetàr), ki je imel značaj pogodbe. (Tosato 1982, 95-99)

Tudi v skladu s klasičnim judovskim pravom, kakor ga prinašata Talmud iz petega in Mišna iz tretjega stoletja pr. Kr. (Neudecker 1980, 7-8; Segre 1980, 22), so judje sklepali zakon v treh ločenih dejanjih. Zaroka je imela dve stopnji. Prvemu delu (Shidduchin) je sledil drugi korak (Erusin ali Kiddushin), zadnje dejanje je bila poroka (Nissuin). Glede na pravne učinke poročnih slovesnosti je bila najvažnejša druga stopnja, ki je veljala za konstitutivni akt zakona. (Frankel 1860, 75-84; DaDon 2018, 133)

\subsection{Zaroka (shidduchin)}

V trenutku zaroke sta se zaročenca skupaj s starši dogovorila glede datuma, kraja, dote in drugih podrobnostih poročne slovesnosti. Sporazum je bil najprej usten, kasneje pa je bil sklenjen v pisni obliki, čeprav je zadostoval 
tudi zgolj ustni dogovor. (Colorni 1945, 182-183) Zgodovinsko je izpričano, da je tak pisni poročni dogovor obstajal že konec petega stoletja pr. Kr., vendar pa ta pravni akt ni predstavljal konstitutivnega elementa, ki bi bil za veljavnost privolitve v zakon obvezen. (Tosato 1982, 106) Bistveni del te prve stopnje poročne slovesnosti je bil v dogovoru glede trdnega namena sklenitve zakona, pri katerem so pomembno vlogo igrali starši obeh strank. V skladu z judovskim pravom je predporočni dogovor pomenil predvsem dvoje: obljubo zaročenca, da se bo poročil z zaročeno nevesto ta obljuba je imela tudi časovni načrt, kdaj se bo to zgodilo - in obljubo staršev ali skrbnikov, kdo bo poravnal stroške poroke. (Homolka 2009, 62)

Judovsko pravo je predvidevalo tudi postopke $\mathrm{v}$ primeru razdrtja zaroke. Obljuba poroke je imela to posebnost, da ni bilo mogoče terjati njene dejanske izpolnitve, vendar pa je lahko v primeru razdrtja drugi zaročenec terjal odškodnino za materialno in tudi nematerialno škodo. Zadeva se je lahko obravnavala tudi na sodišču, ki je lahko kršitelja pogodbe kaznovalo. (Goldfine 1975, 9) Materialna škoda je zadevala dejanske stroške, ki so bili povezani s samo zaročno slovesnostjo, čeprav slednji v zaročni pogodbi niso bili izrecno navedeni, so se pa z dejstvom zaroke predpostavljali. Nematerialna škoda, kot sta sram in izguba dobrega imena, pa je morala biti predvidena v sami pogodbi. (Homolka 2009, 63)

\subsection{Posvetitev (kiddushin) in poroka (nissuin)}

Drugi del zaročne slovesnosti (kiddushin) je bil po Talmudu izvršen z izmenjavo darov oz. vrednih predmetov ali s spolnim dejanjem. (Colorni 1945, 182; Tosato 1982, 86) Pri tem je treba izpostaviti, da je morala zaročenka, razen v primeru mladoletnosti, privolitev izreči sama. Izražena volja poročiti se je morala biti svobodna in prostovoljna. S tem konkretnim dejanjem izročitve žene možu (erussin) sta zaročenca postala mož in žena, kljub temu pa sta običajno še nekaj časa ostala vsak na svojem domu. Omenjeni drugi korak v okviru poročnih slovesnosti je glede pravnih posledic za zaročence bistven, pri čemer med kiddushin in erussin ni jasnega razlikovanja. Od tega trenutka dalje sta stranki imeli poleg zakonskih pravic tudi dolžnosti, ki jih ni bilo mogoče preklicati. Slednje so prenehale s smrtjo enega od zaročencev ali z ločitvijo. (Neudecker 1980, 9-10) V judovski Postavi izraza kiddushin ne najdemo, v svetopisemskih besedilih Peteroknjižja besedo običajno nadomeščata glagola vzeti 
ali dobiti. ${ }^{2}$ Abraham npr. naroči svojemu služabniku, naj ne vzame žene izmed kanaanskega ljudstva, temveč naj si jo dobi iz svojega rodu $(5 \mathrm{Mz}$ 24,3-4). Izraz kiddushin se je uporabljal predvsem v ustni rabi in v razlagi Postave. Kiddushin pomeni dejanje izročitve drug drugemu in posvetitve zakoncev, vendar ne v smislu krščanskega zakramentalnega zakona, temveč predstavlja pravno predstopnjo od Boga blagoslovljene zakonske zveze med moškim in žensko. (Homolka 2009, 71)

Iz razlage traktata kiddushin iz zbirke Mišna razberemo, da je mož lahko pridobil ženo na naslednje načine: $z$ denarjem, listino ali s tem, da je z njo spal. Lahko jo je dobil z ločitveno listino ali če je bila žena vdova. (Homolka 2009, 72-73; Meacham 2020, 1-2) Te načine je judovsko pravo dovoljevalo, med njimi pa je bila v praktičnem življenju glede izbire načina poroke razlika. Prvi način pridobitve žene, s spolnim dejanjem, ki je moral biti potrjen z dvema pričama (bT Qid 9b), so v praksi začeli vse bolj zavračati. Pisni dokument (bT Qid 9a-b), s katerim si je mož vzel ženo pred pričami, so izbirali redko. V praksi se je običajno uporabljal tretji način. Mož si je vzel nevesto za ženo s plačilom v denarju ali z vredno stvarjo. Ta način prisvojitve žene se je v praksi obdržal skozi stoletja. Po mnenju nekaterih avtorjev je tudi v postbibličnem času poročno obredje ohranilo antično tradicijo, tj. poroko s preprosto pogodbo in prevzemom neveste. Obred se je odvil po zgledu sklepanja drugih nepremičninskih pogodb oz. s plačilom, s pisnim dokumentom oz. s prisvojitvijo. ${ }^{3}$ (Colorni 1945, 182)

Po preteku določenega časa sta v judovstvu zaročenca obhajala tretjo stopnjo poročne slovesnosti (nissuin), tj. poroko v pravem pomenu besede, ko se je žena po prejemu očetovega blagoslova preselila k možu, s čimer je bil poročni obred zaključen. (Tosato 1980, 109) Poročnemu slavju so prisostvovale tudi priče, $\mathrm{z}$ začetkom skupnega bivanja se je

2 "Izrazi so po celotni hebrejski Bibliji, v različnih sklopih besedil, raztreseni neenakomerno. Vsako besedilo pretresa isti družbeni pojav pod nekoliko drugačnim zornim kotom, saj je hebrejsko Sveto pismo sestavljeno iz mnogih prvin in izročil različnega izvora." (Skralovnik 2015, 81)

3 Prvi kristjani, ki so izšli iz judovstva, so ohranili nekoliko poenostavljeno hebrejsko tradicijo in poroko obhajali v dveh korakih: s prvim, desponsatio, je prišlo do izmenjave privolitve v zakon, $\mathrm{z}$ drugim, sponsalia, pa je po določenem času prišlo do dejanske sklenitve zakona. (Dauvillier in De Clercq 1936, 48-50; Anné 1935, 513-515)

4 Novejša dognanja izpričujejo, da sta zaročenca v Judeji v II. st. po Kristusu lahko sobivala še pred zadnjim poročnim dejanjem, kar pa ni bilo dovoljeno npr. v Galileji. (Ilan 1993, 247-248) 
domnevalo, da je bil zakon tudi izvršen. Zadnje dejanje, s katerim je bil zakon sklenjen in potrjen, je bilo spolno dejanje novoporočencev. Žena je s tem trenutkom postala deležna vseh pravic in je možu glede tega postala enakovredna. (Navarrete 1980, 134) Poročne stopnje kiddushin in nissuin so se, zgodovinsko gledano, v praksi spreminjale. V antiki je bilo v skladu s pravnim virom Mišna med drugo in tretjo stopnjo poroke, če je bila nevesta še devica, navadno obdobje dvanajstih mesecev, v primeru vdove ali ločene žene pa najmanj en mesec. Obreda sta se izjemoma lahko odvila tudi skupaj. (Homolka 2009, 69)

Judovske poročne slovesnosti so se v navzočnosti dveh prič judovske veroizpovedi lahko odvijale doma ali na javnem kraju, vedno pa sta jo spremljali dve posebnosti; obred je imel slovesen in javen značaj. Poroka se je lahko odvijala ob katerikoli uri dneva. Po rabinski tradiciji je bila poroka ob sredah, kadar je bila nevesta devica, oz. ob četrtkih, kadar je bila ločena ali vdova. Poleg tega je bila poroka prepovedana ob sobotah in na nekatere druge praznične dni ali v času posta. (Homolka 2009, 74) V nekaterih zgodovinskih trenutkih je poroki prisostvoval tudi rabin, ki je novoporočence blagoslovil, vendar pa njegova prisotnost za veljavnost privolitve ni bila nujna. Za sklenitev poroke je bila bistvena privolitev zaročencev, ki predstavlja konstitutiven element sklenitve zakona, rabinski blagoslov pa se razume zgolj kot priprošnja Jahveju, iz katerega zaročenca v veri v enega Boga dobivata Božjo moč. (Matjaž 2015, 67) Blagoslov novoporočencev ne predstavlja konstitutivnega elementa sklenitve zakona, ${ }^{5}$ ima pa judovski zakon vedno sakralen značaj in je hkrati preroška podoba zaveze med Jahvejem in izraelskim ljudstvom. (Friedberg 1965, 6; Freisen 1893, 95; Prader 1992, 193)

\section{Vprašanje ločitve}

V razpravi smo že poudarili, da ima zakonska zveza v klasičnem judovstvu sakralen značaj in zelo velik pomen za družinsko srečo in družbo. Praviloma je bila, kot beremo v Svetem pismu, zveza trajna. »Kdor je našel ženo, je našel nekaj dobrega, prejel je milost od Gospoda.«(Prg 18,22)

5 Enako prakso najdemo kasneje tudi pri Grkih. (Zhishman 1864, 137, op. 2) 
Preroki so poroko razumeli kot izpolnitev Postave, sam zakon med možem in ženo pa kot podobo zaveze med Bogom Jahvejem in izraelskim ljudstvom, kjer je poudarjena zvestoba in trajnost Božje obljube in posledično tudi zakonske zveze (Iz 54,5; Jer 31,31-33; Ez 16,8; Oz 2,21-22). Prerok Malahija izrecno graja izraelsko ljudstvo, ki je odpadlo od Boga, in ga primerja z nezvestim možem (2,14-16). Tudi rabinska tradicija poudarja, da sta ločitev zakoncev in nezvestoba tragedija. (Homolka 2009, 114) V primeru napetosti $\mathrm{v}$ družini in $\mathrm{v}$ partnerskih odnosih so si prizadevali za spravo med zakoncema in so jo poveličevali, če je uspela (Moore 1927, 122). Vzrok poudarjanja zakonske zvestobe in trajnosti zakona je bil tudi v dejstvu, da ločitev prinaša škodo otrokom in družbi, predvsem pa je bil izpostavljen duhovni vidik, prelom svete zaveze, ki je bila sklenjena po Božji volji.

Zaradi človeške slabosti in izkušnje ločitev je tudi judovsko pravo za skrajne primere predvidelo postopke ločitve. Pri tem so izhajali s stališča, da je v primerih, kjer je prišlo do ločitve zakoncev, prizadeta tudi svetost zakona. Če med staršema otrok ni bilo več ljubezni, bi to otrokom posledično lahko povzročilo veliko škodo, zato je bila ločitev v tem primeru dopustna. (Gittelsohn 1976, 37-39) V starozavezni judovski tradiciji je bila ločitev stvar moža in najde pravno podlago v sami Postavi. Če mož na ženi najde kaj mrzkega, jo lahko odslovi z ločitveno listino, vendar je, potem ko se je poročila $z$ drugim in se je torej tudi od njega ločila, ne sme vzeti nazaj (5 Mz 24,1-4). Na tem svetopisemskem besedilu o ločitvi je rabinska tradicija razvila pravno prakso ločitve, ki se je kasneje v različnih rabinskih šolah razlagala različno. (Homolka 2009, 117) Po eni od rabinskih razlag je bila mrzka stvar na ženi predvsem njena nezvestoba ali prešuštvo (bT Git 90a-b), po drugih razlagah pa je zadostovalo nezadovoljstvo moža zaradi njenega obnašanja in vsakdanjih reči (bT Git 90a). Tradicionalno gledano, so bili lahko na strani moža ločitveni razlogi v ženinem prešuštvu in nemoralnosti (5 Mz 22,13-19), če je odpadla od judovstva ali možu odrekala pravico do spolnih dejanj ali brez tehtnega razloga zavračala življenje na njegovem domu. Tudi neplodnost je bila lahko vzrok za ločitev, če je trajala deset let $(5 \mathrm{Mz} 7,14)$, prav tako so bili lahko ločitveni razlogi psihične narave, posledica česar je bila nezmožnost za zakon, če je to mož odkril po sklenitvi zakona. V primeru ločitve zaradi suma ženine nezvestobe sta bili potrebni priči. (Homolka 2009, 117) 
Tudi žena je lahko uveljavljala ločitev, npr. če je bil mož nezvest ali če je odpadel od judovstva (Goldfine 1975, 81), če je bil do nje nasilen in jo je poniževal in zapostavljal ter ji odrekel vzdrževanje, če je bil na begu zaradi suma kaznivega dejanja ali nezmožen spolnega dejanja, kar naj bi trajalo vsaj eno leto. Za postopek ločitve je bilo pristojno rabinsko sodišče. (Klein 1979, 450-461)

\section{Sklep}

Za zakonsko zvezo v klasičnem judovstvu je značilno, da je poroka izpolnitev Postave in simbolizira zavezo med Bogom in izraelskim ljudstvom. Med tremi stopnjami poročne slovesnosti je bistveni in konstitutivni element sklenitev pogodbe drugi korak poročnega obreda kiddushin, kar pomeni posvetitev. Omenjena beseda ima isti koren kot qadòsch, ki jo prevajamo s svet. Poudarek svetosti in posvečenosti zakonske zveze je v povezavi z besedilom Postave, kjer Gospod govori Mojzesu: „Govori vsej skupnosti Izraelovih sinov in jim reci: Bodite sveti, kajti jaz, Gospod vaš Bog, sem svet.« (3 Mz 19,1) To Božje naročilo, poudarja Segre, predstavlja obenem versko in moralno zapoved ter pravni predpis, ki ga je treba izvrševati tudi s sklenitvijo zakonske zveze, da se na ta način izvrši Božja volja in nadaljuje potomstvo. (1980, 23) V judovskem pojmovanju zakona izstopa na eni strani poudarjanje svetosti in trajnosti zakona ter grajanje nezvestobe, na drugi strani pa se zaradi človeške slabosti dopušča ločitev in ponovna poroka, ki je bila vedno dovoljena samo znotraj izvoljenega ljudstva. V času očakov so imeli pri izbiri moža in žene veliko vlogo njuni starši, vendar pa je v skladu z rabinsko sodno prakso odločitev za zakon dejanje svobodne volje moža in žene, da izpolnita Božjo zapoved in v ljubezni do Boga in drug do drugega rodita otroke. Institut zakona je posvečen in presega njune osebne interese ali pričakovanja njunih družin. Je v dobro vsega izraelskega ljudstva in izpolnitev Postave. Judovstvo je visoko cenilo združitev moža in žene s spolnim dejanjem, na kar so gledali kot na nekaj normalnega in v sozvočju s harmonijo ustvarjenega sveta. Kjer se združita mož in žena, je Bog med njima. Velik pomen je imela obreza moških, ki je bila znamenje zaveze (1 Mz 17,11-12), hkrati pa je bila tudi poziv k svetosti in odgovornosti na področju zakonske spolnosti. (Segre 1980, 27) Rabinska sodišča so imela v nekaterih primerih tudi pristojnost koga prisiliti k poroki, če se v določenem času ni poročil sam. Neporočenost je bila 
v neskladju s Postavo. Pri sklepanju zakona so bile obvezne navzočnost prič in izmenjava prstanov ter predpisane molitve. Prisotnost judovskega verskega služabnika pri poroki v času očakov ni izpričana, prav tako ne, da bi poroka morala biti v svetišču. Judje niso poznali delitve na civilno in religiozno obliko poroke, ker so izhajali iz dejstva, da je zakon dejanje vere, ki prežema celotno življenje posamezne osebe. Na tej podlagi je kasneje tudi krščanstvo, ki za razliko od judovstva in pod vplivom rimskega prava konstitutivni element zakona vidi v privolitvi zaročencev v zakon, poudarjalo pomen vere predvsem kot podlage za uresničitev zakonskega Življenja. (Slatinek 2018, 403) 


\section{Kratice}

bT Babilonski Talmud

Git Gittin, traktat iz dela Mišna

Qid Qidduschin, traktat iz dela Mišna

ZCP Zakonik cerkvenega prava 1983

\section{Reference}

Anné, Lucien. 1935. La conclusion du mariage dans la tradition et le droit de l'Église jusqu'au VI siècle. Ephemerides Theologicae Lovanienses 12: 513-550. Https://doi.org/10.2143/etl.82.4.2018918

Avsenik Nabergoj, Irena. 2020. Sočutje faraonove hčere v Svetem pismu in maščevalna pravičnost Medeje v grški drami. Edinost in dialog 75/1: 17-39. Https://doi. org/10.34291/edinost/75/avsenik2

Colorni, Vittore. 1945. Legge ebraica e leggi locali. Milano: Giuffrè.

Commissione teologica internazionale. 1977. La dottrina cattolica sul sacramento del matrimonio. Http://www.vatican.va/roman_ curia/congregations/cfaith/cti_documents/ rc_cti_1977_sacramento-matrimonio_it.html\#"TESTO_DELLE_PROPOSIZIONI (pridobljeno 2. 1. 2021).

Correns, Dietrich, ur. 2005. Die Mischna: das grundlegende enzyklopädische Regelwerk rabbinischer Tradition. Wiesbaden: Marix Verlag.

DaDon, Kotel. 2018. Role of the Wife in the Jewish Marriage in Old Testament Scripture, in Jewish Law, and in Rabbinic Literature. Kairos: Evangelical Journal of Theology 12: 129-158. Https:// doi.org/10.32862/k.12.2.2

Dauvillier, Jean, in Charles De Clercq. 1936. Le mariage en Droit Canonique Oriental. Pariz: Sirey.

DellaPergola, Sergio. 2003. Jewish OutMarriage: A Global Perspective. Https:// www.researchgate.net/publication/267223712_ Jewish_Out-Marriage_A_Global_Perspective (pridobljeno 18. 2. 2021).

Frankel, Zacharias. 1860. Grundlinien des mosaisch-talmudischen Eherechts. Monatsschrift für Geschichte und Wissenschaft des Judentums 9: 75-84.
Freisen, Josef. 1893. Geschichte des kanonischen Eherechts bis zum Verfall der Glossenliteratur. Paderborn: Scientia Verlag.

Friedberg, Emil. 1965. Das Recht der Eheschließung in seiner geschichtlichen Entwicklung. Aalen: Scientia.

Gaudemet, Jean. 1989. Il matrimonio in Occidente. Torino: Società editrice internazionale.

Gittelsohn, Roland Bertram. 1976. Love, Sex and Marriage: a Jewish view. New York: Union of American Hebrew Congregations.

Globokar, Roman. 2019. Normativnost človeške narave v času biotehnološkega izpopolnjevanja človeka. Bogoslovni vestnik 79/3: 611-628. Https://doi. org/10.34291/bv2019/03/globokar

Goldfine, Yitzhak. 1975. Jüdisches und Israelisches Eherecht: unter Berücksichtigung des Problems der Zuständigkeit der israelischen Gerichte und der Konfliktregeln. Hamburg: Hamburger Gesellschaft für Völkerrecht und Auswertige Politik.

Goldschmitd, Lazarus, ur. 1980. Der Babylonische Talmud. Königstein: Ts. Jüdischer Verlag.

Homolka, Walter. 2009. Das Jüdische Eherecht. Berlin: De Gruyter Recht.

Ilan, Tal. 1993. Premarital Cohabitation in Ancient Judea: The Evidence of the Babatha Archive and the Mishnah (Ketubbot 1.4). The Harvard Theological Review 86: 247-264. Https:// doi.org/10.1017/s0017816000031229

Klein, Isaac. 1979. A Guide to Jewish Religious Practice. New York: Jewish Theological Seminary of America. 
Krašovec, Jože. 2016. Metaphor, Symbol and Personification in Presentations of Life and Values. Bogoslovni vestnik 76/3: 571-584.

Lattes, Dante. 1976. Morale e diritto nell'ebraismo. La Rassegna Mensile di Israel 42/9-10: 300-305. Https://www.jstor.org/ stable/41284346 (pridobljeno 2. 1. 2021).

Matjaž, Maksimilijan. 2015. Pavlova »beseda o križu« v 1 Kor 1-2 kot izziv krščanske hermenevtike in etike. Bogoslovni vestnik 75/1: 65-78.

Meacham, Tirzah. 2020. Legal-Religious Status of the Married Woman. The Encyclopedia of Jewish Woman. Https://jwa.org/encyclopedia/article/legal-religious-status-of-married-woman (pridobljeno 18. 2. 2021).

Menachem, Elon. 1994. Jewish Law: History, Sources, Principles. Vol. 1. Philadelphia: Jewish Publication Society.

Moore, George Foot. 1927. Judaism in the First Centuries of the Christian Era, the Age of the Tannaim. Vol. 2. Cambridge: Harvard University Press.

Navarrete, Urbano. 1980. Il matrimonio nel diritto canonico: Natura del consenso matrimoniale. V: La definizione essenziale giuridica del matrimonio: Atti del colloquio romanistico-canonistico, 13-16 marzo 1979, 125-139. Rim: Libreria Editrice della Pontificia Università Lateranense.

Neudecker, Reinhard. 1980. Il matrimonio in fieri nel diritto giudaico. V: $L a$ definizione essenziale giuridica del matrimonio: Atti del colloquio romanistico-canonistico, 13-16 marzo 1979, 7-18. Rim: Libreria Editrice della Pontificia Università Lateranense.

Palmisano, Maria Carmela. 2020. Dimensioni di giustizia in alcuni testi sapienziali biblici. Edinost in dialog 75/1: 41-49. Https://doi.org/10.34291/edinost/75/palmisano

Prader, Josef. 1992. Il matrimonio in Oriente $e$ Occidente. Rim: Pontificio Istituto Orientale.
Ritzer, Korbinian. 1962. Formen, Riten und religiöses Brauchtum der Eheschließung in den christlichen Kirchen des ersten Jahrtausends. Münster: Aschendorffsche Verlagsbuchhandlung.

Saje, Andrej. 2003. La forma straordinaria e il ministro della celebrazione del matrimonio secondo il codice latino e orientale. Rim: Pontificia Università Gregoriana.

- - -. 2009. Morala in pravo. V: Ivan Janez Štuhec in Anton Mlinar, ur. Leksikon krščanske etike. Elektronska izdaja. Celje; Ljubljana: Celjska Mohorjeva družba.

- - -. 2018. Vpliv poročnih praks starih kultur na sklepanje zakona prvih kristjanov. Bogoslouni vestnik 78/3: 813-823.

Segre, Augusto. 1980. Il matrimonio nel diritto ebraico. V: La definizione essenziale giuridica del matrimonio: Atti del colloquio romanistico-canonistico, 13-16 marzo 1979, 19-28. Rim: Libreria Editrice della Pontificia Università Lateranense.

Skralovnik, Samo. 2015. Relativna in absolutna revščina v hebrejščini, v klasični in v novozavezni grščini. Bogoslovni vestnik 75/1: 79-98.

Skralovnik, Samo, in Maksimilijan Matjaž. 2020. The Old Testament Background of ,desire' in 1 Cor 10:6 [Starozavezno ozadje ,poželenja‘ v 1 Kor 10,6]. Bogoslouni vestnik 80/3: 505-518. Https://doi.org/10.34291/bv2020/03/skralovnik

Slatinek, Stanislav. 2018. Vera zaročencev in poročna obljuba. Bogoslovni vestnik 78/2: 401-413.

Tosato, Angelo. 1982. Il matrimonio israelitico: una teoria generale. Rim: Pontificio instituto biblico.

Zakonik cerkvenega prava. 1983. Ljubljana: Nadškofijski ordinariat.

Zhishman, Joseph. 1864. Das Eherecht der orientalischen Kirche. Dunaj: Braumüll. 